\title{
Microencapsulação de Lactobacillus Acidophilus Utilizando Extrato Hidrossolúvel de Soja Como Agente Encapsulante
}

Leidiane Andreia Acordi Menezes (I), Deisy Alessandra Drunkler (I)

(I) UTFPR-MD - Universidade Tecnológica Federal do Paraná (Av. Brasil, 4232 - Parque Independência, Medianeira, Paraná, Brasil.)

\section{Resumo}

A microencapsulação é uma tecnologia capaz de empacotar materiais em pequenas cápsulas, que liberam seu conteúdo sob condições específicas, considerada promissora como alternativa para preservar a viabilidade de culturas probióticas em alimentos, cuja eficácia depende, entre outros fatores, do material escolhido como agente encapsulante. O presente trabalho avaliou a viabilidade do emprego de extrato de soja em pó como material de parede para a formação de microcápsulas. Os materiais a serem utilizados como agentes encapsulantes - extrato de soja em pó e maltodextrina - foram dispersos em água estéril, em proporção de 2:1, até obtenção de solução com concentração de $15 \%(\mathrm{~m} / \mathrm{v})$. A cultura probiótica de L. acidophilus foi adicionada a $1 \%(\mathrm{~m} / \mathrm{v})$ e homogeneizada em incubadora shaker. Em seguida a solução foi submetida à secagem em spray dryer de escala laboratorial (MSD 1.0, Labmaq do Brasil, São José do Rio Preto, Brasil), operado com temperatura de entrada de ar de $85^{\circ} \mathrm{C}$, vazão de alimentação de $0,54 \mathrm{~L} / \mathrm{h}$ e vazão do ar de secagem de $0,40 \mathrm{~L} / \mathrm{min}$. $\mathrm{O}$ pó de microcápsulas foi coletado e armazenado sob congelamento a $18^{\circ} \mathrm{C}$ em frascos estéreis. Os efeitos do processo de microencapsulação sobre a viabilidade da cultura foram avaliados mediante enumeração de células viáveis de L. acidophilus na solução de alimentação e no pó das microcápsulas, em duplicata. A redução da viabilidade foi expressa em ciclos log como o valor logarítmico da fração de sobrevivência relativa, dado o número de células viáveis antes e após a atomização. Amostras do 
pó foram observadas por microscopia óptica para caracterização visual da microestrutura. A contagem inicial foi de 12,55 $\pm 0,01 \log$ UFC.g-1 na solução de alimentação e de 11,32 \pm 0,27 log UFC.g-1 no pó obtido após o processo de secagem. A redução da viabilidade foi de 1,23 ciclos log, indicando alta sobrevivência da cultura e demonstrando a proteção adequada oferecida pelos agentes encapsulantes. $\mathrm{O}$ rendimento do processo foi de 90,2\%, considerado satisfatório quando comparados a outros trabalhos. A observação microscópica permitiu a visualização da efetiva formação de microcápsulas, que apresentaram formato esférico, tamanho variado e superfície ligeiramente irregular. Tais resultados indicam que o extrato de soja em pó associado à maltodextrina é apropriado para o emprego como material de parede na encapsulação de micro-organismos.

Palavras-Chave: Encapsulação, Probióticos, Soja Agência de Fomento: $\mathrm{CNPq}$ 